\title{
ElF5A wt Allele
}

National Cancer Institute

\section{Source}

National Cancer Institute. EIF5A wt Allele. NCI Thesaurus. Code C91354.

Human EIF5A wild-type allele is located within 17p13-p12 and is approximately $5 \mathrm{~kb}$ in length. This allele, which encodes eukaryotic translation initiation factor 5A-1 protein, is involved in the modulation of apoptotic signaling and both elongation and stability of mRNA transcripts. 